\title{
The effects of selenium feed supplements on the oxidative stability indicators of egg yolk during the laying period
}

\author{
Miroslava Fašiangová ${ }^{1}$, Gabriela Bořilová ${ }^{1}$, Danka Haruštiakováe,3, Dana Kumprechtová4, \\ Miroslav Cigánek ${ }^{5}$, Radka Hulánková ${ }^{1}$, Eric Auclair ${ }^{6}$, Ruth Raspoet $^{6}$ \\ ${ }^{1}$ University of Veterinary Sciences Brno, Faculty of Veterinary Hygiene and Ecology, \\ Department of Animal Origin Food and Gastronomic Sciences, Brno, Czech Republic \\ ${ }^{2}$ Masaryk University, Faculty of Medicine, Institute of Biostatistics and Analyses, Brno, Czech Republic \\ ${ }^{3}$ Masaryk University, Faculty of Science, RECETOX, Brno, Czech Republic \\ ${ }^{4}$ Institute of Animal Science Prague, Department of Animal Nutrition, Prague, Czech Republic \\ ${ }^{5}$ Veterinary Research Institute, Department of Chemistry and Toxicology, Brno, Czech Republic \\ ${ }^{6}$ Phileo by Lesaffre, Marcq-en-Baroeul, France
}

Received February 25, 2021

Accepted November 9, 2021

\begin{abstract}
The aim of this study was to assess the effects of four types of selenium (Se) feed supplements on the indicators of the oxidative stability of egg yolk. A total of 1,740 Bovans Brown laying hens were divided into 4 experimental and 1 control group. The diets fed to the experimental groups were supplemented with $0.2 \mathrm{mg} / \mathrm{kg}$ of Se, provided as sodium selenite, Se-enriched yeast, synthetic L-selenomethionine and hydroxy-analogue of selenomethionine.

The highest concentrations of MDA, an indicator of secondary lipid oxidation, were confirmed in the Control Group eggs $(P<0.001)$. Egg yolks from the Control Group were found to have the highest lightness $(P=0.032)$, the lowest colour chroma and the lowest proportions of the red and yellow colours $(P<0.001)$. The highest vitelline membrane strength was measured in eggs from groups fed diets supplemented with organic Se $(P<0.001)$. No significant differences were found between groups in the total fatty acid content, the content of saturated and unsaturated fatty acids or the n-6/n-3 fatty acid ratios. Our study confirmed the effect of Se feed supplements on the concentration of MDA and the colour indicators of egg yolk and on the vitelline membrane strength.
\end{abstract}

Organic Se, inorganic Se, lipid oxidation, chicken

Oxidative changes in eggs, and changes in yolk lipids in particular, may be delayed by supplementing layer feed with antioxidants. Along with vitamin E, selenium (Se) is an important component of the antioxidant system involved in the reduction of lipid peroxidation (Mohiti-Asli et al. 2008; Ren et al. 2010; Wu et al. 2011; Zdunczyk et al. 2013; Tufarelli 2014). Selenium prevents the formation of lipid peroxides in cells, which protects the cells from oxidative damage (Muhammad et al. 2021). Vitamin E supplementation is commonly used in eggs enriched with n-3 fatty acids susceptible to oxidation (Ren et al. 2010). The need for vitamin $\mathrm{E}$ in layer feed may potentially be reduced by an appropriate form and level of Se-based feed supplements (Zdunczyk et al. 2013). Various types of feed additives containing Se in inorganic or organic form are available on the market today. The most commonly used inorganic form of Se is sodium selenite. Sodium selenite is a source of Se utilized for immediate selenoprotein synthesis, but its ability to build up Se reserves in the body is limited (Skrivan et al. 2006; Heindl et al. 2010; Kinal et al. 2012). Organic form of Se has much higher bioavailability (Skrivan et al. 2006; Pavlovic et al. 2009). The organic forms of Se used in animal nutrition include Se-enriched yeast (Skrivan et al. 2006; Heindl et al. 2010; Arpasova et al. 2012; Jing et al. 2015), synthetic selenomethionine (Skrivan et al. 2010; Jing et al. 2015), Se-enriched alga Chlorella (Skrivan et al. 2006; Heindl et al. 2010; Surai and Fisinin 
2014), and possibly also garden cress (Finley et al. 2001), spring onion (Kapolna and Fodor 2006) and garlic (Tsuneyoshi et al. 2006). The high bioavailability of organic Se is partly due to the way of its absorption. Absorption of organic Se takes place via an active transport mechanism, whereas inorganic Se is absorbed by passive diffusion (Kinal et al. 2012). Moreover, organic Se not used in protein synthesis is utilized to build up Se reserves concentrated in the muscles and eggs (Heindl et al. 2010).

Several studies have demonstrated that Se addition to layer feed increases Se concentrations in eggs and thereby prolongs the shelf life of eggs by increasing the oxidative stability of egg lipids and proteins (Pappas et al. 2005; Mohiti-Asli et al. 2008; Wang et al. 2010; Wu et al. 2011). In order to assess the effect of Se in feed, a long-term study was conducted involving a large number of variables, some of which (e.g. production data) will need to be published separately. The aims of the present work were to monitor the effects of Se feed supplements on the indicators of oxidative stability of egg yolk and to compare the effects of the various Se supplements on the indicators monitored.

Table 1. Composition of the basal diet.

\begin{tabular}{|c|c|}
\hline Ingredients & Content \\
\hline Wheat (\%) & 18.954 \\
\hline Maize (\%) & 40.000 \\
\hline Soybean meal (\%) & 18.200 \\
\hline Wheat bran $(\%)$ & 7.000 \\
\hline Fish meal $(\%)$ & 2.000 \\
\hline Soybean oil (\%) & 1.900 \\
\hline Lysine-HCl (\%) & 0.030 \\
\hline DL-methionine $(\%)$ & 0.160 \\
\hline Arbocell Cell Fibre (\%) & 1.700 \\
\hline Salt $(\%)$ & 0.310 \\
\hline Limestone (\%) & 2.950 \\
\hline Limestone, roughly ground (\%) & 6.000 \\
\hline $\operatorname{MCP}(\%)$ & 0.570 \\
\hline Vitamin and mineral supplementation (\%) & 0.226 \\
\hline Crude protein $(\mathrm{g} / \mathrm{kg})$ & 172.66 \\
\hline Fat $(\mathrm{g} / \mathrm{kg})$ & 46.39 \\
\hline Linoleic acid (g/kg) & 23.01 \\
\hline Crude fibre $(\mathrm{g} / \mathrm{kg})$ & 45.92 \\
\hline $\mathrm{ME}(\mathrm{MJ} / \mathrm{kg})$ & 11.52 \\
\hline Lysine $(\mathrm{g} / \mathrm{kg})$ & 8.46 \\
\hline Methionine (g/kg) & 4.25 \\
\hline Methionine + cysteine $(\mathrm{g} / \mathrm{kg})$ & 7.29 \\
\hline Threonine (g/kg) & 6.12 \\
\hline Tryptophan (g/kg) & 2.07 \\
\hline $\mathrm{Ca}(\mathrm{g} / \mathrm{kg})$ & 38.21 \\
\hline $\mathrm{P}(\mathrm{g} / \mathrm{kg})$ & 5.82 \\
\hline $\mathrm{P}$ (digestible) (g/kg) & 4.00 \\
\hline $\mathrm{Na}(\mathrm{g} / \mathrm{kg})$ & 1.61 \\
\hline$\overline{\text { Vitamin A (UI/kg) }}$ & 12948.03 \\
\hline Vitamin D3 (UI/kg) & 2496.00 \\
\hline
\end{tabular}

MCP - monocalcium phosphate; ME - metabolisable energy

\section{Materials and Methods}

In the study, 1,740 Bovans Brown hybrid laying hens aged 133 days were divided into 4 experimental groups $(n=420$ /group) and 1 Control Group $(n=60)$. The diets of experimental groups were supplemented with $0.2 \mathrm{mg} / \mathrm{kg}$ Se from four different sources, i.e. sodium selenite (Group 1), Se-enriched yeast (Group 2), synthetic L-selenomethionine (Group 3) and hydroxy-analogue of selenomethionine (Group 4). The birds in the Control Group (Group C) were fed basal feed with no supplementation. The total Se content in feed (analysed in the $1^{\text {st }}, 5^{\text {th }}$ and $9^{\text {th }}$ laying periods) was $261 \mu \mathrm{g} / \mathrm{kg}$ in basal feed and 517, 522, 508 and $494 \mu \mathrm{g} /$ $\mathrm{kg}$ in feed for Group 1, 2, 3 and 4, respectively. Experimental diets were fed to the hens for 8 months, consisting of 9 experimental periods of 28 days each. The detailed composition of the basal diet is given in Table 1 .

The laying hens were reared in a three-tier furnished cage system with $750 \mathrm{~cm}^{2}$ of floor area per bird, with 30 birds per cage. The cage system used in the experiment met the requirements for furnished cage systems set out in Decree 464/2009 Coll., amending Decree 208/2004 Coll. on minimum standards for the protection of farm animals as amended by Decree 425/2005 Coll. The battery cages were placed in a climatecontrolled windowless hall with an ambient temperature of $19 \pm 1{ }^{\circ} \mathrm{C}$ and a relative humidity of $65 \pm 5 \%$. The temperature control system consisted of vacuum fans and suction valves. A gas-fired heating unit was used during cold periods. Automatic ventilation provided air exchange at a rate of at least $3 \mathrm{~m}^{3}$ per hour per 1 $\mathrm{kg}$ live weight in winter and $5 \mathrm{~m}^{3}$ per hour per 1 $\mathrm{kg}$ live weight in summer. The laying hens were fed twice a day.

In each laying period, a total of 640 eggs were collected and stored at $16 \pm 2{ }^{\circ} \mathrm{C}$ in a dry and dark place. A thiobarbituric acid test (TBA) and yolk $\mathrm{pH}$ analysis were performed on these samples of fresh eggs on the 
day of laying and on Days 14, 28 and 35 of storage. Moreover, the fatty acid content and the strength of the vitelline membrane were determined in samples of fresh eggs on the day of laying and on Day 35 of storage. An instrumental colour analysis was performed on yolks of fresh eggs on the day of laying.

Thiobarbituric acid test

The TBA value was determined in yolk of fresh eggs and eggs 14, 28, and 35 days old. The analysis was carried out according to Castellini et al. (2002). The oxidation products were quantified as the amount of malondialdehyde (MDA) that produced a pink colour after reaction with 2-thiobarbituric acid. Colour intensity was determined by spectrophotometry (Thermo Fisher Scientific, Model Genesys 6, Massachusetts, USA) at a wavelength of $532 \mathrm{~nm}$. The TBA value was reported in milligrams of MDA per kg of sample. The following formula was used to calculate the MDA content:

$\mathrm{MDA}=7.8 \times \mathrm{A} \times 10^{-1} \times \mathrm{m}^{-1}$

where MDA - concentration of malondialdehyde ( $\mathrm{mg} / \mathrm{kg}) ; \mathrm{A}$ - absorbance at $532 \mathrm{~nm}$;

$\mathrm{m}$ - weight of sample $(\mathrm{g})$.

1. Yolk $\mathrm{pH}$ determination

The $\mathrm{pH}$ of yolk was determined in fresh eggs and eggs 14,28, and 35 days old. The yolk $\mathrm{pH}$ was determined on a 340i pH meter (WTW GmbH, Weilheim, Germany) with an insertion electrode (SenTIX SP, WTW GmbH).

2. Fatty acid determination

The fatty acid content was determined in egg yolk of fresh and 35-day-old eggs. The principle of fatty acid analysis was the lipid extraction of the samples examined, followed by re-esterification of fatty acids. Their identification and quantification were performed by gas chromatography in combination with a Saturn 2100T ion trap GC/MS System mass spectrometer (Varian, Walnut Creek, CA, USA). All fatty acids were quantified using authentic standards.

Instrumental analysis of yolk membrane strength

Instrumental analysis of yolk membrane strength was determined in fresh and 35-day-old eggs. The yolk membrane strength was determined on an Instron Universal Testing Machine, Model 5544 (Instron Corporation, High Wycombe, UK) with a puncture probe. The cross head speed was set at $50 \mathrm{~mm} / \mathrm{min}$ and the load at $2 \mathrm{kN}$. The data were obtained using Merlin software, Series IX (Merlin, Richardson, USA). The strength was expressed as the force $(\mathrm{N})$ needed to break the vitelline membrane.

Instrumental colour analysis of egg yolk

Instrumental colour analysis of yolks (CIEL*a*b* colour system) was performed on fresh eggs only using a KonicaMinolta Colorimeter CM 2600d (Minolta, Osaka, Japan) and standard illuminant light source D65 for average daylight (including the ultraviolet wavelength region). Lightness $\left(\mathrm{L}^{*}\right)$, redness $\left(\mathrm{a}^{*}\right)$, yellowness $\left(\mathrm{b}^{*}\right)$ and chroma $\left(C^{*}\right)$ of the sample were calculated using available software (Spectra Magic 3.61). Three measurements were made directly on each egg yolk surface.

Selenium content determination

Determination of Se content in feed and eggs was described previously (Borilova et al. 2020).

Statistical analysis

General linear model - analysis of variance (ANOVA) was used to analyse the data. The model included the effect of diet (Group $1-4$, control), laying period $\left(1^{\text {st }}, 5^{\text {th }}\right.$ and $\left.9^{\text {th }}\right)$ and days of storage $(0,14,28,35)$ as well as their interaction. Tukey HSD was used as post hoc test.

The relationship between the vitelline membrane strength and egg yolk $\mathrm{pH}$ was assessed by the non-parametric Spearman-rank correlation $\left(r_{s}\right)$. As these characteristics were determined in different eggs, data had to be aggregated for the defined group/period/day of storage before performing the correlation test. This operation resulted in a small number of observations and use of nonparametric correlation coefficient.

$P<0.05$ was regarded as significant in all tests. Statistical analyses were performed with IBM SPSS Statistics, version 22 (IBM Corp., Armonk, NY, USA) and Statistica, version 12 (StatSoft, Tulsa, OK, USA).

\section{Results}

The average content of Se in yolk among the experimental groups varied from 489 (Group 2) to 559 (Group 4) $\mu \mathrm{g} / \mathrm{kg}$, whereas in Group C the average concentration was only $359 \mu \mathrm{g} / \mathrm{kg}$ (Table 2). Compared to the total Se content in feed, the hydroxy-analogue of selenomethionine (Group 4) showed the best deposition efficiency, and the Se-enriched yeast (Group 2) the worst. The Se content in yolk was strongly influenced by the laying period - the total amount was the highest in young birds in the $1^{\text {st }}$ period (Table 2). 
Table 2. Effect of diet group and laying period on content of selenium $(\mu \mathrm{g} / \mathrm{kg})$ in fresh egg yolk $(\mathrm{mean} \pm \mathrm{SEM})$.

\begin{tabular}{lccccc}
\hline $\begin{array}{l}\text { Laying } \\
\text { period }\end{array}$ & Group 1 & Group 2 & Group 3 & Group 4 & Group C \\
\hline 1 & $618.39 \pm 23.55^{\mathrm{Aa}}$ & $602.91 \pm 21.99^{\mathrm{Aab}}$ & $664.39 \pm 21.91^{\mathrm{Aa}}$ & $638.76 \pm 23.33^{\mathrm{Aa}}$ & $491.89 \pm 11.61^{\mathrm{Ab}}$ \\
5 & $445.44 \pm 15.01^{\mathrm{Ba}}$ & $399.61 \pm 17.90^{\mathrm{Ba}}$ & $493.38 \pm 26.74^{\mathrm{Ba}}$ & $456.65 \pm 23.33^{\mathrm{Ba}}$ & $242.80 \pm 13.79^{\mathrm{Bb}}$ \\
9 & $477.50 \pm 15.20^{\mathrm{Ba}}$ & $350.05 \pm 45.25^{\mathrm{Bbc}}$ & $442.27 \pm 19.94^{\mathrm{Bab}}$ & $481.60 \pm 41.10^{\mathrm{Ba}}$ & $241.84 \pm 12.25^{\mathrm{Bc}}$ \\
\hline
\end{tabular}

GLM - ANOVA result: effect of the diet: $P<0.001$; effect of the laying period: $P<0.001$; effect of the diet and laying period interaction: $P=0.169$.

Group 1 - basal diet supplemented with $0.2 \mathrm{mg} / \mathrm{kg}$ from sodium selenite, Group 2 - basal diet supplemented with $0.2 \mathrm{mg} / \mathrm{kg}$ from Se-enriched yeast, Group 3 - basal diet supplemented with $0.2 \mathrm{mg} / \mathrm{kg}$ from synthetic L-selenomethionine, Group 4 - basal diet supplemented with $0.2 \mathrm{mg} / \mathrm{kg}$ from hydroxy-analogue of selenomethionine, Group C - Control Group.

A-B different superscripts indicate significant differences within the column; ${ }^{a-c}$ different superscripts indicate significant differences within the row.

Table 3. The effect of the diet, laying period, and storage of eggs on malondialdehyde concentration ( $\mathrm{mg} / \mathrm{kg})$ in egg yolk (mean \pm SEM).

\begin{tabular}{lcccccc}
\hline $\begin{array}{l}\text { Day of } \\
\text { storage }\end{array}$ & $\begin{array}{c}\text { Laying } \\
\text { period }\end{array}$ & Group 1 & Group 2 & Group 3 & Group 4 & Group C \\
\hline 0 & 1 & $2.105 \pm 0.106^{\mathrm{ABa}}$ & $1.996 \pm 0.213^{\mathrm{Aa}}$ & $1.555 \pm 0.080^{\mathrm{Ab}}$ & $1.798 \pm 0.165^{\mathrm{ABab}}$ & $1.824 \pm 0.050^{\mathrm{ABCab}}$ \\
& 5 & $1.169 \pm 0.021^{\mathrm{Cab}}$ & $0.971 \pm 0.050^{\mathrm{Bab}}$ & $0.816 \pm 0.036^{\mathrm{Ba}}$ & $0.898 \pm 0.036^{\mathrm{Ca}}$ & $1.362 \pm 0.029^{\mathrm{ADb}}$ \\
& 9 & $1.202 \pm 0.032^{\mathrm{C}}$ & $1.157 \pm 0.055^{\mathrm{BC}}$ & $1.138 \pm 0.025^{\mathrm{BC}}$ & $1.213 \pm 0.027^{\mathrm{CD}}$ & $1.431 \pm 0.045^{\mathrm{ABD}}$ \\
14 & 1 & $1.140 \pm 0.082^{\mathrm{Ca}}$ & $1.965 \pm 0.092^{\mathrm{Ab}}$ & $1.484 \pm 0.076^{\mathrm{ACa}}$ & $1.409 \pm 0.085^{\mathrm{ADa}}$ & $1.054 \pm 0.069^{\mathrm{Da}}$ \\
& 5 & $1.367 \pm 0.034^{\mathrm{CD}}$ & $1.378 \pm 0.020^{\mathrm{C}}$ & $1.293 \pm 0.054^{\mathrm{AC}}$ & $1.284 \pm 0.030^{\mathrm{CD}}$ & $1.542 \pm 0.046^{\mathrm{ABD}}$ \\
& 9 & $1.400 \pm 0.033^{\mathrm{CDa}}$ & $1.338 \pm 0.055^{\mathrm{BCa}}$ & $1.353 \pm 0.056^{\mathrm{ACa}}$ & $1.331 \pm 0.051^{\mathrm{Da}}$ & $1.831 \pm 0.093^{\mathrm{BCb}}$ \\
& 1 & $1.951 \pm 0.059^{\mathrm{AE}}$ & $2.165 \pm 0.090^{\mathrm{A}}$ & $2.009 \pm 0.061^{\mathrm{D}}$ & $2.075 \pm 0.022^{\mathrm{B}}$ & $2.287 \pm 0.076^{\mathrm{CE}}$ \\
& 5 & $1.622 \pm 0.043^{\mathrm{DEab}}$ & $1.393 \pm 0.035^{\mathrm{Cab}}$ & $1.308 \pm 0.023^{\mathrm{ACa}}$ & $1.453 \pm 0.054^{\mathrm{ADab}}$ & $1.761 \pm 0.046^{\mathrm{ABCEb}}$ \\
& 9 & $1.604 \pm 0.075^{\mathrm{DE}}$ & $1.521 \pm 0.097^{\mathrm{C}}$ & $1.504 \pm 0.064^{\mathrm{AC}}$ & $1.519 \pm 0.034^{\mathrm{AD}}$ & $1.687 \pm 0.047^{\mathrm{AB}}$ \\
& 1 & $2.179 \pm 0.088^{\mathrm{A}}$ & $2.199 \pm 0.130^{\mathrm{A}}$ & $2.141 \pm 0.102^{\mathrm{D}}$ & $2.000 \pm 0.070^{\mathrm{B}}$ & $2.335 \pm 0.022^{\mathrm{C}}$ \\
& 5 & $1.456 \pm 0.031^{\mathrm{CDab}}$ & $1.202 \pm 0.076^{\mathrm{BCa}}$ & $1.347 \pm 0.021^{\mathrm{ACab}}$ & $1.349 \pm 0.028^{\mathrm{Dab}}$ & $1.738 \pm 0.035^{\mathrm{ABEb}}$ \\
& 9 & $1.715 \pm 0.044^{\mathrm{BCD}}$ & $1.452 \pm 0.047^{\mathrm{C}}$ & $1.505 \pm 0.059^{\mathrm{AC}}$ & $1.506 \pm 0.040^{\mathrm{AD}}$ & $1.714 \pm 0.084^{\mathrm{ABE}}$ \\
\hline
\end{tabular}

GLM - ANOVA result: effect of the diet: $P<0.001$; effect of the laying period: $P<0.001$; effect of the day of storage: $P<0.001$; effect of the diet, laying period, and day of storage interaction: $P<0.001$.

Group 1 - basal diet supplemented with $0.2 \mathrm{mg} / \mathrm{kg}$ from sodium selenite, Group 2 - basal diet supplemented with $0.2 \mathrm{mg} / \mathrm{kg}$ from Se-enriched yeast, Group 3 - basal diet supplemented with $0.2 \mathrm{mg} / \mathrm{kg}$ from synthetic L-selenomethionine, Group 4 - basal diet supplemented with $0.2 \mathrm{mg} / \mathrm{kg}$ from hydroxy-analogue of selenomethionine, Group C - Control Group.

A-E different lsuperscripts indicate significant differences within the column; ${ }^{\text {a-b }}$ different superscripts indicate significant differences within the row.

The results of the TBA test analysis showed a significant effect of Se feed supplements on the level of MDA contained in egg yolk $(P<0.001)$. When comparing TBA values in eggs from different groups, the highest values were found in Group C eggs (Control Group; Table 3). Their TBA values were significantly different from those found in eggs from all the other groups $(P<0.001)$. No significant differences were, however, found between eggs from groups fed diets supplemented with different forms of Se. The effect of period and storage day was also significant $(P<0.001)$ with the highest TBA values in eggs from the $1^{\text {st }}$ laying period (Table 3$)$. The products of oxidation increased toward the end of storage $(P<0.001)$.

We found no significant differences in the fatty acid content between groups (Table 4). The total fatty acid content and the content of individual types of fatty acids showed no significant relationship with the Se content in the yolk $(P>0.05)$; however, they were 


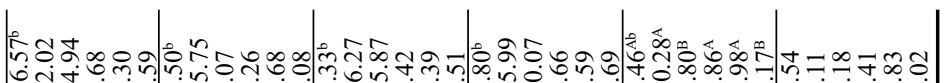

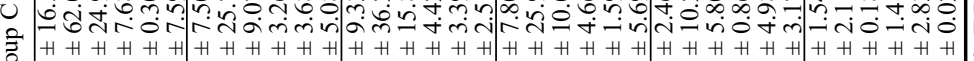

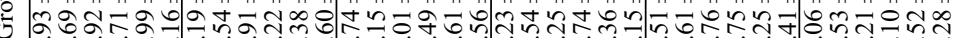

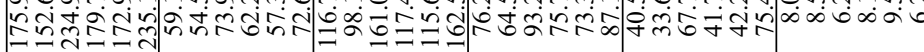

m

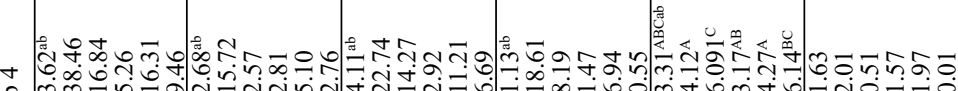

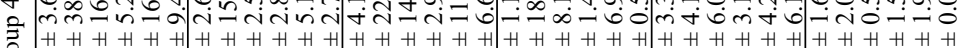

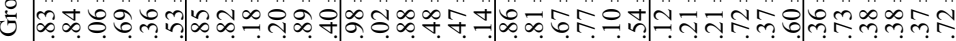
तु

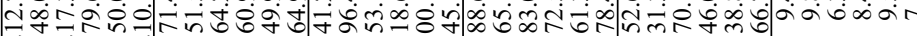

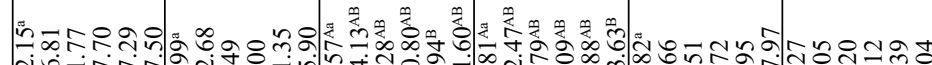

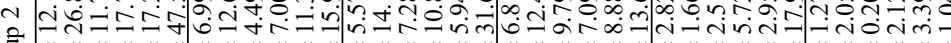
产 H H H H H H H H H H H H H H H H H H H H H H H H H H H H H H H H H H H H - Tom तुં (1)

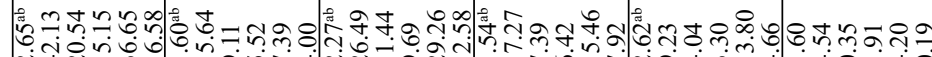

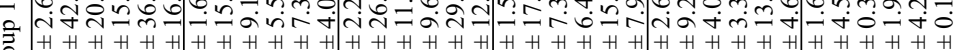

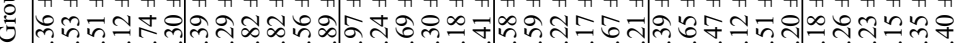

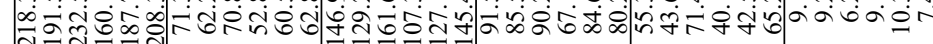


affected by the storage of eggs and laying period as the lowest total fatty acid content was in the $5^{\text {th }}$ period and the ratio of $n-6 / n-3$ fatty acids was the lowest in the $9^{\text {th }}$ period for all the groups $(P=0.012)$. The amount of all fatty acids significantly decreased after 35 days of storage $(P<0.001)$.

The highest values of yolk lightness were confirmed in eggs from the Control Group $(P=0.032)$. No significant differences in the yolk lightness were confirmed in eggs from groups supplemented with different forms of Se; the only statistical difference in lightness was found between Group 4 and the Control Group $(P=0.039)$. As the age of hens increased, so did the lightness values of yolk $(P<0.001)$ with the highest values in the $9^{\text {th }}$ period (Table 5). The lowest proportions of the red and yellow colours were confirmed in eggs from the Control Group which were significantly different from the eggs in all the other groups $(P=0.001)$. The analysis of the proportions of red colour also showed a significant difference between eggs from Groups 1 and $4(P=0.041$, Table 5). The lowest yolk colour chroma was found in eggs from the Control Group $(P<0.001)$. The $\mathrm{a}^{*}, \mathrm{~b}^{*}$ and $\mathrm{C}^{*}$ colour indicators were significantly affected also by the laying period (Table 5 ) as there was a significant decrease in the $9^{\text {th }}$ period $(P<0.001)$.

The instrumental analysis of vitelline membrane strength confirmed significant differences between groups $(P<0.001$; Table 6$)$. The highest vitelline membrane strength was found in eggs from groups fed diets supplemented with organic Se (Groups 2-4). Significantly lower vitelline membrane strength compared to eggs from the other groups was found in Group $\mathrm{C}$ eggs $(P<0.001)$. Eggs from the group supplemented with inorganic Se had significantly lower yolk membrane strength than eggs from the groups fed diets supplemented with organic Se $(P<0.001)$.

Table 5. The effect of the diet and laying period on colour indicators of egg yolk (mean \pm SEM).

\begin{tabular}{ccccccc}
\hline & $\begin{array}{c}\text { Laying } \\
\text { period }\end{array}$ & Group 1 & Group 2 & Group 3 & Group 4 & Group C \\
\hline $\mathrm{L}^{*}$ & 1 & $62.08 \pm 0.44^{\mathrm{Aa}}$ & $62.89 \pm 0.49^{\mathrm{Aab}}$ & $62.83 \pm 0.41^{\mathrm{Aab}}$ & $62.65 \pm 0.46^{\mathrm{Aab}}$ & $63.73 \pm 0.66^{\mathrm{Ab}}$ \\
& 5 & $64.32 \pm 0.25^{\mathrm{B}}$ & $64.38 \pm 0.16^{\mathrm{A}}$ & $64.21 \pm 0.31^{\mathrm{A}}$ & $64.42 \pm 0.22^{\mathrm{A}}$ & $64.39 \pm 0.35^{\mathrm{A}}$ \\
& 9 & $65.97 \pm 0.19^{\mathrm{C}}$ & $65.39 \pm 0.44^{\mathrm{B}}$ & $65.47 \pm 0.55^{\mathrm{B}}$ & $65.50 \pm 0.33^{\mathrm{B}}$ & $65.98 \pm 0.33^{\mathrm{B}}$ \\
$\mathrm{a}^{*}$ & 1 & $13.36 \pm 0.19^{\mathrm{Aa}}$ & $12.09 \pm 0.46^{\mathrm{Aab}}$ & $12.12 \pm 0.27^{\mathrm{Aab}}$ & $12.42 \pm 0.20^{\mathrm{Aab}}$ & $11.68 \pm 0.48^{\mathrm{Ab}}$ \\
& 5 & $12.44 \pm 0.28^{\mathrm{Ba}}$ & $11.94 \pm 0.16^{\mathrm{Aab}}$ & $11.96 \pm 0.21^{\mathrm{Aab}}$ & $11.36 \pm 0.21^{\mathrm{Ab}}$ & $12.48 \pm 0.38^{\mathrm{Aab}}$ \\
& 9 & $9.57 \pm 0.45^{\mathrm{Ca}}$ & $9.68 \pm 0.45^{\mathrm{Ba}}$ & $10.17 \pm 0.49^{\mathrm{Ba}}$ & $9.43 \pm 0.43^{\mathrm{Ba}}$ & $7.90 \pm 0.17^{\mathrm{Bb}}$ \\
$\mathrm{b}^{*}$ & 1 & $64.47 \pm 0.92^{\mathrm{A}}$ & $62.62 \pm 1.32^{\mathrm{A}}$ & $62.74 \pm 1.23^{\mathrm{A}}$ & $62.81 \pm 0.57^{\mathrm{A}}$ & $63.23 \pm 1.52^{\mathrm{A}}$ \\
& 5 & $64.53 \pm 0.70^{\mathrm{Ba}}$ & $62.79 \pm 0.63^{\mathrm{Aab}}$ & $62.79 \pm 0.83^{\mathrm{Aab}}$ & $62.42 \pm 0.67^{\mathrm{Ab}}$ & $61.60 \pm 0.31^{\mathrm{Ab}}$ \\
& 9 & $59.79 \pm 0.68^{\mathrm{Ca}}$ & $58.54 \pm 0.77^{\mathrm{Bab}}$ & $59.16 \pm 0.68^{\mathrm{Bab}}$ & $57.38 \pm 0.78^{\mathrm{Bb}}$ & $57.32 \pm 0.58^{\mathrm{Bb}}$ \\
$\mathrm{C}^{*}$ & 1 & $65.84 \pm 0.91^{\mathrm{A}}$ & $63.78 \pm 1.37^{\mathrm{A}}$ & $63.90 \pm 1.24^{\mathrm{A}}$ & $64.03 \pm 0.59^{\mathrm{A}}$ & $64.30 \pm 1.57^{\mathrm{A}}$ \\
& 5 & $65.72 \pm 0.73^{\mathrm{Aa}}$ & $63.91 \pm 0.64^{\mathrm{Aab}}$ & $63.92 \pm 0.85^{\mathrm{Aab}}$ & $63.45 \pm 0.69^{\mathrm{Ab}}$ & $62.86 \pm 0.32^{\mathrm{Ab}}$ \\
& 9 & $60.57 \pm 0.72^{\mathrm{Ba}}$ & $59.34 \pm 0.83^{\mathrm{Babc}}$ & $60.05 \pm 0.70^{\mathrm{Bab}}$ & $58.16 \pm 0.82^{\mathrm{Bbd}}$ & $57.86 \pm 0.58^{\mathrm{Bcd}}$ \\
\hline
\end{tabular}

$\mathrm{L}^{*}$ lightness, $\mathrm{a} *$ redness, $\mathrm{b} *$ yellowness, $\mathrm{C}^{*}$ chroma.

GLM - ANOVA result for $L^{*}$ : effect of the diet: $P=0.018$; effect of the laying period: $P<0.001$; effect of the diet and laying period interaction: $P=0.025$. GLM - ANOVA result for a*: effect of the diet: $P<0.001$; effect of the laying period: $P<0.001$; effect of the diet and laying period interaction: $P<0.001$. GLM - ANOVA result for $\mathrm{b}^{*}$ : effect of the diet: $P<0.001$; effect of the laying period: $P<0.001$; effect of the diet and laying period interaction: $P=0.322$. GLM - ANOVA result for $\mathrm{C}^{*}$ : effect of the diet: $P<0.001$; effect of laying period: $P<0.001$; effect of the diet and laying period interaction: $P=0.330$.

Group 1 - basal diet supplemented with $0.2 \mathrm{mg} / \mathrm{kg}$ from sodium selenite, Group 2 - basal diet supplemented with $0.2 \mathrm{mg} / \mathrm{kg}$ from Se-enriched yeast, Group 3 - basal diet supplemented with $0.2 \mathrm{mg} / \mathrm{kg}$ from synthetic L-selenomethionine, Group 4 - basal diet supplemented with $0.2 \mathrm{mg} / \mathrm{kg}$ from hydroxy-analogue of selenomethionine, Group C - Control Group.

A-C different superscripts indicate significant differences within the column; ${ }^{\text {a-b }}$ different superscripts indicate significant differences within the row. 
Table 6. The effect of the diet, laying period, and storage of eggs on egg yolk vitelline membrane strength $(\mathrm{mN}$, mean $\pm \mathrm{SEM})$.

\begin{tabular}{lcccccc}
\hline $\begin{array}{l}\text { Day of } \\
\text { storage }\end{array}$ & $\begin{array}{c}\text { Laying } \\
\text { period }\end{array}$ & Group 1 & Group 2 & Group 3 & Group 4 & Group C \\
\hline 0 & 1 & $54.00 \pm 2.27^{\mathrm{Aa}}$ & $61.50 \pm 0.92^{\mathrm{Ab}}$ & $61.67 \pm 2.46^{\mathrm{Ab}}$ & $61.33 \pm 1.33^{\mathrm{Ab}}$ & $49.33 \pm 0.76^{\mathrm{Ac}}$ \\
& 5 & $52.83 \pm 1.62^{\mathrm{Aa}}$ & $60.33 \pm 1.43^{\mathrm{Ab}}$ & $61.17 \pm 1.19^{\mathrm{Ab}}$ & $66.50 \pm 2.74^{\mathrm{Abc}}$ & $48.17 \pm 0.83^{\mathrm{Ad}}$ \\
& 9 & $52.50 \pm 3.60^{\mathrm{ABa}}$ & $60.33 \pm 1.02^{\mathrm{Ab}}$ & $60.50 \pm 1.48^{\mathrm{ABb}}$ & $60.17 \pm 0.54^{\mathrm{Ab}}$ & $46.00 \pm 2.45^{\mathrm{ABc}}$ \\
35 & 1 & $48.17 \pm 1.70^{\mathrm{CDa}}$ & $59.67 \pm 0.80^{\mathrm{Ab}}$ & $56.50 \pm 2.74^{\mathrm{BCb}}$ & $56.00 \pm 1.32^{\mathrm{Cc}}$ & $42.67 \pm 1.45^{\mathrm{BCd}}$ \\
& 5 & $45.00 \pm 1.59^{\mathrm{Ca}}$ & $54.00 \pm 1.15^{\mathrm{Bb}}$ & $51.00 \pm 2.71^{\mathrm{Db}}$ & $53.67 \pm 0.92^{\mathrm{Cb}}$ & $41.67 \pm 1.38^{\mathrm{Ca}}$ \\
& 9 & $48.83 \pm 0.60^{\mathrm{BDa}}$ & $52.33 \pm 0.33^{\mathrm{Bb}}$ & $53.00 \pm 1.10^{\mathrm{CDbc}}$ & $55.17 \pm 1.19^{\mathrm{Cc}}$ & $37.50 \pm 1.50^{\mathrm{Dd}}$ \\
\hline
\end{tabular}

GLM - ANOVA result: effect of the diet: $P<0.001$; effect of the laying period: $P<0.001$; effect of the day of storage: $P<0.001$; effect of the diet, laying period, and day of storage interaction: $P=0.402$.

Group 1 - basal diet supplemented with $0.2 \mathrm{mg} / \mathrm{kg}$ from sodium selenite, Group 2 - basal diet supplemented with $0.2 \mathrm{mg} / \mathrm{kg}$ from Se-enriched yeast, Group 3 - basal diet supplemented with $0.2 \mathrm{mg} / \mathrm{kg}$ from synthetic L-selenomethionine, Group 4 - basal diet supplemented with $0.2 \mathrm{mg} / \mathrm{kg}$ from hydroxy-analogue of selenomethionine, Group C - Control Group.

A-C different superscripts indicate significant differences within the column; ${ }^{\text {a-b }}$ different superscripts indicate significant differences within the row.

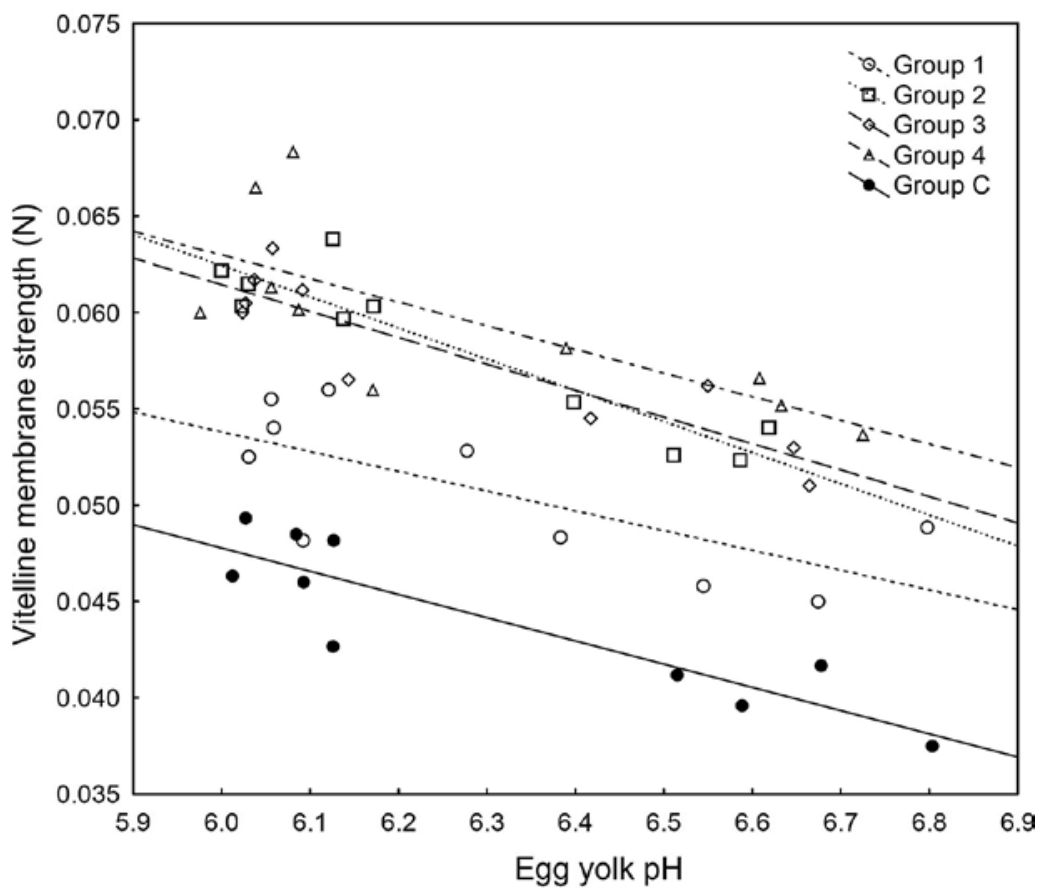

Fig. 1. Relationship between vitelline membrane strength $(\mathrm{N})$ and egg yolk $\mathrm{pH}$ in eggs from experimental groups and Control Group. Group 1 - supplementation with sodium selenite, Group 2 - supplementation with Se-enriched yeast, Group 3 - supplementation with synthetic L-selenomethionine, Group 4 - supplementation with hydroxyanalogue of selenomethionine, group $\mathrm{C}$ - Control Group. 
Table 7. The effect of the diet, laying period, and storage of eggs on yolk $\mathrm{pH}$ (mean $\pm \mathrm{SEM}$ ).

\begin{tabular}{lclllll}
\hline $\begin{array}{l}\text { Day of } \\
\text { storage }\end{array}$ & $\begin{array}{c}\text { Laying } \\
\text { period }\end{array}$ & Group 1 & Group 2 & Group 3 & Group 4 & Group C \\
\hline 0 & 1 & $6.06 \pm 0.02^{\mathrm{A}}$ & $6.03 \pm 0.04^{\mathrm{A}}$ & $6.04 \pm 0.02^{\mathrm{A}}$ & $6.06 \pm 0.01^{\mathrm{AB}}$ & $6.03 \pm 0.04^{\mathrm{A}}$ \\
& 5 & $6.28 \pm 0.15^{\mathrm{AB}}$ & $6.17 \pm 0.03^{\mathrm{A}}$ & $6.09 \pm 0.02^{\mathrm{A}}$ & $6.04 \pm 0.01^{\mathrm{A}}$ & $6.13 \pm 0.04^{\mathrm{A}}$ \\
& 9 & $6.03 \pm 0.02^{\mathrm{A}}$ & $6.02 \pm 0.02^{\mathrm{A}}$ & $6.03 \pm 0.03^{\mathrm{A}}$ & $6.09 \pm 0.01^{\mathrm{AC}}$ & $6.09 \pm 0.01^{\mathrm{A}}$ \\
14 & 1 & $6.27 \pm 0.06^{\mathrm{AB}}$ & $6.20 \pm 0.05^{\mathrm{AB}}$ & $6.26 \pm 0.10^{\mathrm{ABC}}$ & $6.26 \pm 0.10^{\mathrm{ABD}}$ & $6.34 \pm 0.03^{\mathrm{ABC}}$ \\
& 5 & $6.31 \pm 0.04^{\mathrm{AB}}$ & $6.30 \pm 0.01^{\mathrm{AB}}$ & $6.21 \pm 0.02^{\mathrm{A}}$ & $6.40 \pm 0.03^{\mathrm{ABD}}$ & $6.46 \pm 0.06^{\mathrm{ABC}}$ \\
& 9 & $6.07 \pm 0.02^{\mathrm{A}}$ & $6.05 \pm 0.01^{\mathrm{A}}$ & $6.09 \pm 0.03^{\mathrm{A}}$ & $6.20 \pm 0.04^{\mathrm{AB}}$ & $6.18 \pm 0.03^{\mathrm{A}}$ \\
& 1 & $6.41 \pm 0.15^{\mathrm{ABC}}$ & $6.50 \pm 0.09^{\mathrm{AB}}$ & $6.35 \pm 0.08^{\mathrm{ABC}}$ & $6.53 \pm 0.10^{\mathrm{ABD}}$ & $6.21 \pm 0.05^{\mathrm{AB}}$ \\
& 5 & $6.34 \pm 0.05^{\mathrm{AB}}$ & $6.37 \pm 0.13^{\mathrm{AB}}$ & $6.24 \pm 0.06^{\mathrm{AB}}$ & $6.48 \pm 0.24^{\mathrm{BE}}$ & $6.68 \pm 0.05^{\mathrm{BC}}$ \\
& 9 & $6.26 \pm 0.04^{\mathrm{AB}}$ & $6.29 \pm 0.07^{\mathrm{AB}}$ & $6.15 \pm 0.04^{\mathrm{A}}$ & $6.39 \pm 0.05^{\mathrm{BCDE}}$ & $6.20 \pm 0.05^{\mathrm{A}}$ \\
& 1 & $6.09 \pm 0.02^{\mathrm{A}}$ & $6.14 \pm 0.03^{\mathrm{AB}}$ & $6.14 \pm 0.04^{\mathrm{A}}$ & $6.17 \pm 0.04^{\mathrm{AEF}}$ & $6.13 \pm 0.04^{\mathrm{A}}$ \\
& 5 & $6.67 \pm 0.10^{\mathrm{BC}}$ & $6.62 \pm 0.07^{\mathrm{B}}$ & $6.66 \pm 0.07^{\mathrm{BC}}$ & $6.73 \pm 0.04^{\mathrm{D}}$ & $6.68 \pm 0.11^{\mathrm{BC}}$ \\
& 9 & $6.80 \pm 0.04^{\mathrm{C}}$ & $6.59 \pm 0.06^{\mathrm{B}}$ & $6.65 \pm 0.04^{\mathrm{C}}$ & $6.63 \pm 0.04^{\mathrm{DF}}$ & $6.80 \pm 0.04^{\mathrm{C}}$ \\
\hline
\end{tabular}

GLM - ANOVA result: effect of the diet: $\mathrm{P}=0.017$; effect of the laying period: $\mathrm{P}<0.001$; effect of the day of storage: $\mathrm{P}<0.001$; effect of the group, laying period, and day of storage interaction: $\mathrm{P}=0.208$.

Group 1 - basal diet supplemented with $0.2 \mathrm{mg} / \mathrm{kg}$ from sodium selenite, Group 2 - basal diet supplemented with $0.2 \mathrm{mg} / \mathrm{kg}$ from Se-enriched yeast, Group 3 - basal diet supplemented with $0.2 \mathrm{mg} / \mathrm{kg}$ from synthetic L-selenomethionine, Group 4 - basal diet supplemented with $0.2 \mathrm{mg} / \mathrm{kg}$ from hydroxy-analogue of selenomethionine, Group C - Control Group.

A-C different superscripts indicate significant differences within the column

No significant differences between eggs from groups supplemented with organic Se were detected. The dependence of vitelline membrane strength on yolk $\mathrm{pH}$ was demonstrated both in the entire set irrespective of groups $\left(\mathrm{r}_{\mathrm{s}}=-0.515\right.$; $P<0.001$; Fig. 1) and individually in Group $2(\mathrm{r}=-0.845 ; P=0.002)$, Group 3 ( $\mathrm{r}=-0.782$; $P=0.008)$, Group $4\left(\mathrm{r}_{\mathrm{s}}=-0.806 ; P=0.005\right)$ and Group $\mathrm{C}\left(\mathrm{r}_{\mathrm{s}}=-0.830 ; \stackrel{\mathrm{s}}{P}=0.003\right.$; Fig. 1). Both indicators were affected by the laying period and changed during storage of eggs (Table 6, Table 7), as the yolk $\mathrm{pH}$ increased and vitelline membrane strength decreased over time in all groups $(P<0.001)$.

\section{Discussion}

Our study has shown that the inclusion of Se into a commercial diet significantly increases the Se concentration in egg yolk, since organic Se in the form of selenomethionine and Se-enriched yeast is more efficient than the inorganic form. These findings correspond with the results of studies by Surai (2002) and Skrivan et al. (2006). The majority of Se in Se-enriched yeast is selenomethionine, a Se analogue of methionine. The chemical similarity between selenomethionine and methionine allows the body to use them interchangeably in protein synthesis, which makes it possible to build Se reserves in eggs (Wang et al. 2010). However, the content of Se in egg yolk decreased in our study as the age of the bird increased. This finding suggests that the mechanism by which Se was absorbed and deposited became less efficient with age or that because Se is required for the operation of the antioxidant system and immune response the demands for Se elsewhere in the body may have increased (Pappas et al. 2005).

Lipids contain triacylglycerols, free fatty acids, xanthophylls, carotenes, vitamins and phospholipids. They consist of molecules with a long chain of carbon atoms connected with many double bonds. These bonds make lipids extremely sensitive to oxidation (Kralik et al. 2014). Lipid peroxidation results in an increase in the content of the secondary oxidation product MDA, characterized by a TBA value, the amount of which increases 
during storage (Mohiti-Asli et al. 2008; Kralik et al. 2014) as was confirmed also in our study where the highest TBA values were observed in stored eggs (Table 3). High TBA values indicate a high degree of lipid oxidation. The addition of Se to layer diets, however, enhances the oxidative stability of egg lipids, thereby reducing the level of MDA. Table 3 shows the increased lipid oxidation stability of eggs from supplemented groups. The oxidative stability of lipids from Se-enriched eggs is higher due to the higher content and activity of the antioxidant enzyme glutathione peroxidase (GSH-Px), in which Se is an essential component (Muhammad et al. 2021). Mohiti-Asli et al. (2008) also found lower MDA values in Se-enriched eggs, but failed to find any differences in the effects of various forms of Se. No differences between supplemented groups as measured by the TBA assay were identified in our study, either, although the lowest TBA values, though nonsignificantly, were found in eggs from Group 2 (supplementation with Se-enriched yeast). On the other hand, Muhammad et al. (2021) proved higher efficiency of organic Se. According to the study of Skrivan et al. (2010), both chemical forms of Se addition have an impact on the MDA concentration in both fresh and stored eggs, however, the impact of the inorganic Se supplementation diminishes during long storage.

Pappas et al. (2005), Mohiti-Asli et al. (2008), and Zdunczyk et al. (2013) reported that increased levels of Se in eggs may affect the composition of fatty acids in yolk lipids. Our study, however, did not confirm any significant differences in the fatty acid content between groups probably due to insufficient sample size. Nevertheless, the fatty acid content changed in our study during storage of eggs. The amount of all fatty acids significantly decreased after 35 days of storage in response especially to lipid peroxidation of polyunsaturated fatty acids with a long chain that are susceptible to peroxidation. Additionally, the proportion of fatty acids in egg yolk changed with the age of the laying hens as well. These results reflect the metabolism of the laying hens, whose requirements for individual fatty acids vary as the age of the bird increases.

The content of lipids in egg yolk and their stability influence the colour of yolk (Seemann 2000; Mohiti-Asli et al. 2010). Yolk colour depends to a large extent on the laying hens' diet (Ren et al. 2010). The stability of yolk pigments is dependent on the oxidative stability of lipids contained in egg yolk (Seemann 2000; Mohiti-Asli et al. 2010). Oxidation of readily oxidizable fatty acids in the digestive tract leads to the reaction between oxidized fatty acids and oxycarotenoids. If oxycarotenoids are oxidized, they lose their pigmentation ability which is reflected in the intensity of the egg yolk colour (Seemann 2000). The causality of the above process suggests that since the stability of yolk lipids increased after Se supplementation in our study, so did the stability of yolk pigments. The results of yolk colour analysis using the CIELAB system confirmed that yolk of Se-enriched eggs had a lower lightness, a higher proportion of the red and yellow colours and a higher colour chroma than yolk of non-enriched eggs (Table 5). Muhammad et al. (2021) also reported lower lightness and higher yellowness values in egg yolks of hens supplemented with organic Se. Mohiti-Asli et al. (2010), who used the HoffmanLa Roche colour scale to determine the colour of egg yolk, found that yolk colour values were significantly higher after supplementation with Se-enriched yeast. In contrast, Mohiti-Asli et al. (2008) and Arpasova et al. (2009) did not confirm a dependence of yolk colour on the Se content in laying hens' feed.

In the present study the vitelline membrane strength decreased during storage. As soon as the egg is laid, its yolk membrane starts losing strength due to the degradation of structural glycoproteins and disulphide bonds of ovumucin in the outer layer of the vitelline membrane (Kirunda and McKee 2000). The degradation of egg proteins leads to a change in $\mathrm{pH}$ of the egg content which explains the significant dependence between the yolk $\mathrm{pH}$ and the vitelline membrane strength values ascertained in our study (Fig. 1). The correlation between yolk $\mathrm{pH}$ and yolk membrane strength was also corroborated by Kirunda and 
McKee (2000). The stability of proteins responsible for vitelline membrane strength also depends on the oxidation processes that take place after an egg has been laid. Wang et al. (2010) and $\mathrm{Wu}$ et al. (2011) demonstrated that the addition of Se to layer feed had a positive effect on the oxidative stability of proteins. In our study the highest yolk membrane strength was confirmed in eggs from the groups enriched with organic Se (Table 6), which corresponds with conclusions of Aljamal et al. (2014) who reported higher values of yolk membrane strength after selenomethionine than after sodium selenite supplementation. However, in our study no differences between various groups supplemented with organic Se were identified.

Our study confirmed the effects of Se feed supplements on the oxidative stability of egg yolk. Significantly lower TBA values characterizing the secondary oxidation of yolk lipids were confirmed in eggs from Se-supplemented groups. Yolks of Se-enriched eggs had a lower lightness, a higher proportion of the red and yellow colours and a higher colour chroma. Furthermore, higher vitelline membrane strength was confirmed in eggs from groups enriched with organic Se (selenomethionine and Se-enriched yeast) compared to non-enriched eggs and eggs enriched with an inorganic form of Se (sodium selenite). It was demonstrated that the vitelline membrane strength depended on the yolk $\mathrm{pH}$. Increasing values of yolk $\mathrm{pH}$ were found to be associated with a decrease in the vitelline membrane strength. Se supplementation had no significant effect on the total content of fatty acids, the content of saturated and unsaturated fatty acids or the n-6/n-3 fatty acid ratio. The oxidative changes and the antioxidative effect of Se were more pronounced in stored eggs.

\section{Acknowledgements}

This research has been financially supported by the Institutional Research Support for VETUNI Brno. Further support was provided by the RECETOX research infrastructure (the Czech Ministry of Education, Youth and Sports; LM2018121) and CETOCOEN EXCELLENCE Teaming 2 project (Horizon 2020; 857560 and the Czech Ministry of Education, Youth and Sports; CZ.02.1.01/0.0/0.0/17_043/0009632). The authors thank the International Poultry Testing, Ustrašice, Czech Republic for cooperation within experimental part of this research.

\section{References}

Aljamal AA, Purdum SE, Hanford KJ 2014: The effect of normal and excessive supple mentation of selenomethionine and sodium selenite in laying hens. Int J Appl Poult Res 3: 33-38

Arpasova H, Hascik P, Kacaniova M, Galik B, Golian J, Mellen M 2012: The effect of various forms and doses of selenium supplementation of the hens diet on selected qualitative parameters and freshness of table eggs. Scientific Papers: Animal Science and Biotechnologies 45: 11-16

Arpasova H, Mellen M, Kacaniova M, Hascik P, Petrovic V, Cobanova K, Leng L 2009: Effects of dietary supplementation of sodium selenite and selenized yeast on selected qualitative parameters of laying hens eggs. Slovak J Anim Sci 42: 27-33

Borilova G, Fasiangova M, Harustiakova D, Kumprechtova D, Illek J, Auclair E, Raspoet R 2020: Effects of selenium feed supplements on functional properties of eggs. J Food Technol 57: 32-40

Castellini C, Mugnai C, Dal Bosco A 2002: Effect of organic production system on broiler carcass and meat quality. Meat Sci 60: 219-225

Finley JW, Ip C, Lisk DJ, Davis CD, Hintze KJ, Whanger PD 2001: Cancer-protective properties of high-selenium broccoli. J Agric Food Chem 49: 2679-2683

Heindl J, Ledvinka Z, Tůmova E, Zita L 2010: The importance, utilization and sources of selenium for poultry: a review. Sci. agric. Bohem 41: 55-64

Jing CL, Dong XF, Wang ZM, Liu S, Tong JM 2015: Comparative study of DL-selenomethionine vs sodium selenite and seleno-yeast on antioxidant activity and selenium status in laying hens. Poult Sci 94: 965-975

Kapolna E, Fodor P 2006: Speciation analysis of selenium enriched green onions (Allium fistulosum) by HPLC-ICP-MS. Microchem J 84: 56-62

Kinal S, Krol B, Tronina W 2012: Effect of various selenium sources on selenium bioavailability, chicken growth performance, carcass characteristics and meat composition of broiler chickens. EJPAU 15: \#07

Kirunda DFK, McKee SR 2000: Relating quality characteristics of aged eggs and fresh eggs to vitelline membrane strength as determined by a texture analyzer. Poult Sci 79: 1189-1193

Kralik Z, Kralik G, Grcevic M, Galovic D 2014: Effect of storage period on the quality of table eggs. Acta Agraria Kaposvariensis 18: 200-206 
Mohiti-Asli M, Shariatmadari F, Lotfollahian H 2010: The influence of dietary vitamin E and selenium on egg production parameters, serum and yolk cholesterol and antibody response of laying hen exposed to high environmental temperature. Arch Geflugelkd 74: 43-50

Mohiti-Asli M, Shariatmadari F, Lotfollahian H, Mazuji MT 2008: Effects of supplementing layer hen diets with selenium and vitamin $\mathrm{E}$ on egg quality, lipid oxidation and fatty acid composition during storage. Can J Anim Sci 88: $475-483$

Muhammad AI, Mohamed DA, Chwen LT, Akit H, Samsudin AA 2021: Effect of sodium selenite, selenium yeast, and bacterial enriched protein on chicken egg yolk color, antioxidant profiles, and oxidative stability. Foods 10: 871

Pappas AC, Acamovic T, Sparks NHC, Surai PF, Mcdevitt RM 2005: Effects of supplementing broiler breeder diets with organic selenium and polyunsaturated fatty acids on egg quality during storage. Poult Sci 84: 865-874

Pavlovic Z, Miletic I, Jokic Z, Sobajic S 2009: The effect of dietary selenium source and level on hen production and egg selenium concentration. Biol Trace Elem Res 131: 263-270

Ren Y, Jianping W, Renema R 2010: Nutritional and Health Attributes of Eggs. In: Guerrero-Legarreta I (Ed.): Handbook of Poultry Science and Technology. John Wiley \& Sons, Inc., Hoboken, New Jersey, pp. 535-578

Seemann M 2000: Factors which influence pigmentation. Lohmann Information 24: 20-26

Skrivan M, Bubancova I, Marounek M, Dlouha G 2010: Selenium and $\alpha$-tocopherol content in eggs produced by hens that were fed diets supplemented with selenomethionine, sodium selenite and vitamin E. Czech J Anim Sci 55: 388-397

Skrivan M, Simane J, Dlouha G, Doucha J 2006: Effect of dietary sodium selenite, Se-enriched yeast and Seenriched Chlorella on egg Se concentration, physical parameters on eggs and laying hens production. Czech J Anim Sci 51: 163-167

Surai PF 2002: Selenium in poultry nutrition 2. Reproduction, egg and meat quality and practical applications. Worlds Poult Sci J 58: 431-450

Surai PF, Fisinin VI 2014: Selenium in poultry breeder nutrition: An update. Anim Feed Sci Technol 191: 1-15

Tsuneyoshi T, Yoshida J, Sasaoka T 2006: Hydroponic cultivation offers a practical means of producing selenium enriched garlic. J Nutr 136: 870S-872S

Tufarelli V 2014: Enhancing egg quality by dietary vitamin E and selenium supplementation. Vitamins and Minerals 3: e131

Wang ZG, Pan XJ, Zhang WQ, Peng ZQ, Zhao RQ, Zhou GH 2010: Methionine and selenium yeast supplementation of the maternal diets affects antioxidant activity of breeding eggs. Poult Sci 89: 931-937

Wu DJ, Pan XJ, Wang ZG, Peng ZQ, Zhao LY, Zhang YW 2011: Effect of maternal selenium and methionine on poultry products (egg and meat) qualities and oxidative stability. In: El-Shemy H (Ed.): Soybean and Nutrition. IntechOpen, pp. 269-288

Zdunczyk Z, Drazbo A, Jankowski J, Juskiewicz J, Antoszkiewicz Z, Troszynska A 2013: The effect of dietary vitamin $E$ and selenium supplements on the fatty acid profile and quality traits of eggs. Archiv Tierzucht 56: 719-732 